\title{
Performance Analysis of Pulmonary Tuberculosis Treatment in Indonesia
}

\author{
Nurul Handayani ${ }^{1}$, Hario Megatsari ${ }^{2}$, Agung Dwi Laksono ${ }^{3}$, Mursyidul Ibad ${ }^{4}$ \\ ${ }^{1}$ Magister Student, Master of Health Policy and Administration Faculty of Public Health, Universitas Airlangga, \\ Surabaya, Indonesia, ${ }^{2}$ Lecturer, Faculty of Public Health, Universitas Airlangga, Surabaya, Indonesia, \\ ${ }^{3}$ Researcher, National Institute of Health Research and Development, the Indonesia Ministry of Health, Jakarta, \\ Indonesia, ${ }^{4}$ Lecturer, Faculty of Health, Nadlatul Ulama University, Surabaya, Indonesia
}

\begin{abstract}
If health workers not treated tuberculosis (TB) patients or the treatment is not complete, it can cause dangerous complications and death. The study aims at analyzing the performance of pulmonary TB treatment in Indonesia. The ecological analysis carried out using secondary data from "Data and Information on the 2018 Indonesia's Health Profile". Apart from the percentage of success in pulmonary tuberculosis treatment as the dependent variable, four other variables analyzed as independent variables were the completeness of pulmonary TB treatment, the smoking population's rate, the ratio of public health centers per district, and the percentage of poor people. Data were analyzed using cross-tabulation. The results show the percentage of successful pulmonary TB treatment that is high tends to be lower in provinces with a low rate of pulmonary TB treatment completeness. Regions with inadequate completeness of pulmonary TB treatment have low pulmonary TB treatment success.Meanwhile, there is a tendency that a high percentage of the population who smokes tends to have a low rate of successful pulmonary TB treatment. Moreover, the high Public Health Centers' ratio tends to be more in provinces with increased pulmonary TB treatment success. Finally, the low percentage of poor people tends to be more in regions with high pulmonary TB treatment success. The study concludes the four independent variables studied were related to the success of pulmonary TB treatment.
\end{abstract}

Keywords: ecological analysis, secondary data, pulmonary tuberculosis, treatment success.

\section{Background}

Tuberculosis (TB) is an infectious disease caused by the bacteria Mycobacterium tuberculosis, which can attack various organs, especially the lungs. If health workers not treated TBpatients, or the treatment is not complete, it can cause dangerous complications and death. TB is estimated to have existed in the world since 5000 years BC, but advances in the discovery and control of TB disease have only occurred in the last two centuries ${ }^{1}$.

\section{Corresponding Author:}

Hario Megatsari

Email: hario.megatsari@fkm.unair.ac.id
Currently, one-third of the world's population is estimated to have been infected by Mycobacterium Tuberculosis. In 2019, WHO estimated that the number of TB cases worldwide would be 10 million cases, consisting of 5.6 million men, 3.2 million women, and 1.2 million children. A total of 1.4 million people died from TB in 2019. The incidence and death rate caused by TB is still very high, and it is even one of the five deadly diseases. Indonesia has a burden of disease with the second-highest number of TB cases in the world after India, according to the $\mathrm{WHO}^{2}$.

Based on a survey conducted by the Ministry of Health of the Republic of Indonesia in 2015 regarding the coverage of pulmonary TB case detection, the results showed that the range of all TB cases in Indonesia in 
2014 was 285,254 cases. Meanwhile, the number of new cases of smear-positive lung TB was 176,677 cases. The percentage of CDR or Case Detection Rate of TB cases in Indonesia is $70.08 \%{ }^{3}$. One of the efforts to control and cope with the number of TB sufferers is medication. The indicator used for the evaluation of treatment is the success rate of the program. The government calculates the treatment success from the cure rate and the complete treatment rate ${ }^{4}$.

In 2018, pulmonary TB treatment (success rate) was the highest in Indonesia in West Sulawesi Province, which was $92.37 \%$. The success of pulmonary TB treatment was the lowest in West Papua Province was $35.88 \%$. The average success rate of pulmonary TB treatment in 34 areas in Indonesia in 2018 was $78.58 \%$. The 2018 Indonesia Basic Health Survey report states that the prevalence of clinical pulmonary TB spread throughout Indonesia is around $1.0 \%$. Several provinces recorded as having prevalence rates above the national figure are Aceh, Jakarta, Yogyakarta, West Sumatra, Riau Islands, West Nusa Tenggara, East Nusa Tenggara, South Sulawesi, Central Sulawesi, and eastern Indonesia 6 .

The success of pulmonary TB treatment as one of the national health problems is now a concern. We need an in-depth analysis of the causative factors to increase it. This study aimed to analyze the success of pulmonary TB treatment in Indonesia.

\section{Materials and Methods}

\section{Study Design}

Table 1. Descriptive Analysis of the Success of Pulmonary TB Treatment in Indonesia in 2018

\begin{tabular}{|c|c|c|c|c|c|}
\hline Statistics & $\begin{array}{c}\text { Percentage of Successful } \\
\text { Treatment for Pulmonary } \\
\text { TB }\end{array}$ & $\begin{array}{l}\text { Percentage of completeness } \\
\text { of pulmonary TB treatment }\end{array}$ & $\begin{array}{c}\text { Percentage of } \\
\text { Population Smokes }\end{array}$ & $\begin{array}{c}\text { The ratio of } \\
\text { Public Health } \\
\text { Center }\end{array}$ & $\begin{array}{l}\text { Percentage of } \\
\text { Poor Population }\end{array}$ \\
\hline $\mathrm{N}$ & 34 & 34 & 34 & 34 & 34 \\
\hline Mean & 78.5862 & 10.9579 & 31.7771 & 1.5456 & 10.6482 \\
\hline Std. Deviation & 11.80766 & 5.31742 & 2.86843 & 1.04999 & 5.67326 \\
\hline Range & 56.49 & 24.69 & 10.76 & 6.57 & 23.88 \\
\hline Minimum & 35.88 & 2.61 & 25.80 & 0.73 & 3.55 \\
\hline Maximum & 92.37 & 27.30 & 36.56 & 7.30 & 27.43 \\
\hline Percentiles 33.333 & 78.3367 & 7.3267 & 30.7333 & 1.3067 & 7.2100 \\
\hline Percentiles 66.666 & 85.5767 & 13.7833 & 32.7600 & 1.4567 & 12.1467 \\
\hline
\end{tabular}

Source: Data and Information on the 2018 Indonesia's Health Profile
The authors use an ecological analysis to design the study. Comparisons between communities, not individuals, rely on environmental studies. The analyzed data is the aggregate data at a specific community or level, the provincial level in this analysis. Aggregate measures, ecological measurements, or global measurements may be variables in an ecological study ${ }^{7,8}$.

\section{Data Source}

The study carried out an analysis using secondary data from "Data and Information on the 2018 Indonesia's Health Profile" 5 . The sample was 34 provinces in Indonesia.

\section{Data Analysis}

The dependent variable in this study is the percentage of successful treatment of pulmonary tuberculosis. This study's independent variables were the completeness of pulmonary TB treatment, the portion of the smoking population, the public health center's ratio per district, and the poor people. All variables consist of three parts of the same size. The data were analyzed by univariate and bivariate. Besides, the bivariate analysis performs using cross-tabulations. The entire analysis process uses SPSS software.

\section{Results and Discussion}

Table 1 shows the variables' descriptive statistics in the ecological analysis of pulmonary TB treatment success in Indonesia. The number of samples is 34 , which are all provinces in Indonesia. 
Table 1 shows a descriptive analysis of the success of pulmonary TB treatment in Indonesia in 2018. Based on Table 1, the lowest percentage of successful pulmonary TB treatment was in West Papua Province at
$35.88 \%$, and the highest was in West Sulawesi Province at $92.37 \%$. Meanwhile, the percentage of success in pulmonary TB treatment on average from 34 provinces was $78.58 \%$.

Table 2. Cross-tabulation of the Success of Pulmonary TB Treatment with Completeness of Pulmonary TB Treatment

\begin{tabular}{|c|c|c|c|c|c|c|}
\hline \multirow{2}{*}{$\begin{array}{c}\text { Completeness of pulmonary } \\
\text { TB treatment }\end{array}$} & \multicolumn{5}{|c|}{$\begin{array}{c}\text { Low } \\
\text { (35.88\%-78.34\%) }\end{array}$} & \multicolumn{2}{|c|}{$\begin{array}{c}\text { Middle } \\
\mathbf{( 7 8 . 3 5 \% - 8 5 . 5 6 \% )}\end{array}$} & \multicolumn{2}{c|}{ High } \\
\cline { 2 - 7 } & $\mathbf{8 5 . 5 7 \% - 9 2 . 3 7 \% )}$ \\
\hline N & $\%$ & N & \% & N & \% \\
\hline $\begin{array}{c}\text { Low } \\
(2.61 \%-7.33 \%)\end{array}$ & 4 & 36.4 & 7 & 58.3 & 1 & 9.1 \\
\hline $\begin{array}{c}\text { Middle } \\
(7.34 \%-13.79 \%)\end{array}$ & 2 & 18.2 & 3 & 25.0 & 6 & 54.5 \\
\hline $\begin{array}{c}\text { High } \\
(13.80 \%-27.30 \%)\end{array}$ & 5 & 45.5 & 2 & 16.7 & 4 & 36.4 \\
\hline Total & 11 & 100 & 12 & 100 & 11 & 100 \\
\hline
\end{tabular}

Source: Data and Information on the 2018 Indonesia's Health Profile

Table 2 shows the cross-tabulation between the success of pulmonary TB treatment and completeness of pulmonary TB treatment. The analysis results show that in provinces with a high percentage of pulmonary TB treatment success, as much as $9.1 \%$ are in a low percentage of completeness of pulmonary TB treatment. Table 2 shows that the rate of successful pulmonary TB treatment that is high tends to be lower in provinces with a low percentage of completeness of pulmonary TB treatment. Areas with the low entirety of pulmonary TB treatment have low pulmonary TB treatment success.

Treatment of sensitive TB patients and RO TB principally consists of two stages: the initial stage and the advanced stage. The treatment phase must be undertaken regularly and correctly by TB patients to recover and minimize the risk of Multi-Drug Resistant TB (MDR) or even Extensively Drug-Resistant (XDR) ${ }^{1}$. The DOTS (Directly Observed Treatment Short Course) strategy is the direct supervision of short-term treatment with every tuberculosis program manager's obligation to focus attention on finding sufferers by microscopic examination. Health worker must observe each patient in swallowing the drug, each drug that the patient swallows must be in front of a supervisor. Health workers must also organize patients' treatment in a management system, distribution with sufficient drug supply. Each patient must then receive good medicine, meaning standard short-term treatment that has been clinically proven to be effective ${ }^{9}$. 
Table 3. Cross-Tabulation of the Success of Pulmonary TB Treatment with a Smoking Population

\begin{tabular}{|c|c|c|c|c|c|c|}
\hline \multirow{3}{*}{$\begin{array}{c}\text { Percentage of Population } \\
\text { Smokes }\end{array}$} & \multicolumn{6}{|c|}{ The Success of Pulmonary TB Treatment } \\
\hline & \multicolumn{2}{|c|}{$\begin{array}{c}\text { Low } \\
(35.88 \%-78.34 \%)\end{array}$} & \multicolumn{2}{|c|}{$\begin{array}{c}\text { Middle } \\
(\mathbf{7 8 . 3 5 \% - 8 5 . 5 6 \% )}\end{array}$} & \multicolumn{2}{|c|}{$\begin{array}{c}\text { High } \\
(85.57 \%-92.37 \%)\end{array}$} \\
\hline & $\mathbf{N}$ & $\%$ & $\mathbf{N}$ & $\%$ & $\mathbf{N}$ & $\%$ \\
\hline $\begin{array}{c}\text { Low } \\
(25.80 \%-30.74 \%)\end{array}$ & 1 & 9.1 & 4 & 33.3 & 6 & 54.5 \\
\hline $\begin{array}{c}\text { Middle } \\
(30.75 \%-32.76 \%)\end{array}$ & 5 & 45.5 & 4 & 33.3 & 3 & 27.3 \\
\hline $\begin{array}{c}\text { High } \\
(32.77 \%-36.56 \%)\end{array}$ & 5 & 45.5 & 4 & 33.3 & 2 & 18.2 \\
\hline Total & 11 & 100 & 12 & 100 & 11 & 100 \\
\hline
\end{tabular}

Source: Data and Information on the 2018 Indonesia's Health Profile

Based on table 3, it appears that the cross-tabulation between the success of pulmonary TB treatment and the smoking population. Table 3 shows the provinces with the highest percentage of lung TB treatment success were provinces with a high rate of smoked people, namely $45.5 \%$. It shows that there is a tendency that a high percentage of the population who smokes tends to have a low rate of successful pulmonary TB treatment.

Smoking is the leading cause of TB, the world's deadliest infectious disease ${ }^{10-12}$. Based on gender, the number of new TB cases in 2017 in men was 1.4 times greater than in women. Even based on the Tuberculosis Prevalence Survey, men's prevalence is three times higher than in women's. The same is true in other countries. It may be because men are more exposed to TB risk factors, such as smoking, and less medication adherence ${ }^{13}$. This survey found that of all male participants who smoked as much as $68.5 \%$ and only $3.7 \%$ of female participants smoked ${ }^{14}$.

Table 4.Cross-tabulation of the Success of Pulmonary TB Treatment with the ratio of Public Health Center per district

\begin{tabular}{|c|c|c|c|c|c|c|}
\hline \multirow{3}{*}{$\begin{array}{l}\text { The ratio of Public Health } \\
\text { Center per district }\end{array}$} & \multicolumn{6}{|c|}{ The Success of Pulmonary TB Treatment } \\
\hline & \multicolumn{2}{|c|}{$\begin{array}{c}\text { Low } \\
(35.88 \%-78.34 \%)\end{array}$} & \multicolumn{2}{|c|}{$\begin{array}{c}\text { Middle } \\
(\mathbf{7 8 . 3 5 \% - 8 5 . 5 6 \% )}\end{array}$} & \multicolumn{2}{|c|}{$\begin{array}{c}\text { High } \\
(85.57 \%-92.37 \%)\end{array}$} \\
\hline & $\mathbf{N}$ & $\%$ & $\mathbf{N}$ & $\%$ & $\mathbf{N}$ & $\%$ \\
\hline $\begin{array}{c}\text { Low } \\
(0.73 \%-1.31 \%)\end{array}$ & 5 & 45.5 & 4 & 33.3 & 2 & 18.2 \\
\hline $\begin{array}{c}\text { Middle } \\
(1.32 \%-1.46 \%)\end{array}$ & 4 & 36.4 & 4 & 33.3 & 4 & 36.4 \\
\hline $\begin{array}{c}\text { High } \\
(1.47 \%-7.30 \%) \\
\end{array}$ & 2 & 18.2 & 4 & 33.3 & 5 & 45.5 \\
\hline Total & 11 & 100 & 12 & 100 & 11 & 100 \\
\hline
\end{tabular}


Source: Data and Information on the 2018 Indonesia's Health Profile

Table 4 shows the cross-tabulation between pulmonary TB treatment's success with the ratio of Public Health Center. The analysis showed that the provinces with a high percentage of pulmonary $\mathrm{TB}$ treatment success, $45.5 \%$ had a high Public Health Center ratio. Table 4 shows that high Public Health Centers' ratio tends to be more in provinces with high pulmonary TB treatment success. Regions with a low proportion of Public Health Center have low pulmonary TB treatment success. In Indonesia, the Public Health Center is the leading health care facility that deals directly with the community ${ }^{15,16}$. Therefore, the pulmonary TB treatment program's success is closely related to the ratio of the Public Health Center per district.

Table 5. Cross-tabulation of the Success of Pulmonary TB Treatment with the Percentage of Poor Population

\begin{tabular}{|c|c|c|c|c|c|c|}
\hline \multirow{3}{*}{$\begin{array}{c}\text { the Percentage of Poor } \\
\text { Population }\end{array}$} & \multicolumn{6}{|c|}{ The Success of Pulmonary TB Treatment } \\
\hline & \multicolumn{2}{|c|}{$\begin{array}{c}\text { Low } \\
(35.88 \%-78.34 \%)\end{array}$} & \multicolumn{2}{|c|}{$\begin{array}{c}\text { Middle } \\
(\mathbf{7 8 . 3 5 \% - 8 5 . 5 6 \% )}\end{array}$} & \multicolumn{2}{|c|}{$\begin{array}{c}\text { High } \\
(85.57 \%-92.37 \%)\end{array}$} \\
\hline & $\mathbf{N}$ & $\%$ & $\mathbf{N}$ & $\%$ & $\mathbf{N}$ & $\%$ \\
\hline $\begin{array}{c}\text { Low } \\
(3.55 \%-7.21 \%)\end{array}$ & 1 & 9.1 & 5 & 41.7 & 6 & 54.5 \\
\hline $\begin{array}{c}\text { Middle } \\
(7.22 \%-12.14 \%)\end{array}$ & 4 & 36.4 & 3 & 25.0 & 4 & 36.4 \\
\hline $\begin{array}{c}\text { High } \\
(12.15 \%-27.43 \%)\end{array}$ & 6 & 54.5 & 4 & 33.3 & 1 & 9.1 \\
\hline Total & 11 & 100 & 12 & 100 & 11 & 100 \\
\hline
\end{tabular}

Source: Data and Information on the 2018 Indonesia's Health Profile

Table 5 shows the cross-tabulation between the success of pulmonary TB treatment with the poor. The results show that the provinces with a high percentage of pulmonary TB treatment success, as much as $54.5 \%$ have a low rate of poor people. Table 5 shows that the low percentage of poor people tends to be more in provinces with high pulmonary TB treatment success. Regions with a high rate of poor people have low TB treatment success. Previous studies found that the factor affecting the use of health facilities for outpatient treatment was wealth status. People with good wealth or socioeconomic status have a great opportunity to better use health facilities for outpatient treatment ${ }^{17,18}$. People with higher wealth status have smaller barriers to access health services, both service and transportation cost barrier $^{19,20}$.

\section{Conclusions}

The research concluded four independent variables studied were related to the success of pulmonary TB treatment. The four variables are completeness of pulmonary TB treatment, Percentage of Smoking Population, Ratio of Public Health Center per district, Percentage of Poor Population.

Acknowledgments: The authors thank the Ministry of Health of the Republic of Indonesia for providing the reports. Through this data, the author can carry out analysis in this manuscript.

\section{Source of Funding: Self-funding}

Ethical Clearance: The study was conducted by utilizing secondary data from published reports. For this 
reason, the study not required ethical clearance in the implementation.

\section{Conflicting Interests: Nil}

\section{References}

1. The Ministry of Health of The Republic of Indonesia. the 2016 Tuberculosis data and information. 2016. p. 12.

2. WHO. WHO TB burden report 2018. Vol. 63, World Health Organization. 2018. 476 p.

3. The Ministry of Health of The Republic of Indonesia. The 2015 Indonesia Health Profile. Jakarta; 2015.

4. Maulidya YN, Redjeki ES, Fanani E. Factors Affecting the Success of Pulmonary Tuberculosis Treatment in Post-Treatment Patients at Dinoyo Public Health Center, Malang City. Prev Indones J Public Heal. 2017;2(1):44.

5. Ministry of Health of The Republic of Indonesia. Data and Information on the 2018 Indonesia's Health Profile. Jakarta; 2018.

6. National Institute of Health Research and Development of The Indonesia Ministry of Health. The2018IndonesiaBasicHealthSurvey(Riskesdas): National Report [Internet]. Jakarta; 2019. Available from: http://labmandat.litbang.depkes. go.id/ images/download/laporan/ RKD/2018/ Laporan $\% 7 \mathrm{~B} \% 5 \mathrm{C}$ \%7DNasional $\% 7 \mathrm{~B} \% 5 \mathrm{C} \_\quad \%$ 7DRKD2018\%7B\%5C_\%7DFINAL.pdf

7. Morgenstern H. Ecologic Studies in Epidemiology: Concepts, Principles, and Methods. Annu Rev Public Health. 1995;16:61-81.

8. Utami SM, Handayani F, Hidayah M, Wulandari RD, Laksono AD. Ecological Analysis of Preeclampsia/Eclampsia Case in Sidoarjo Regency, Indonesia, 2015-2019. Indian J Forensic Med Toxicol. 2020;14(4):3474-9.

9. Samhatul I, Bambang W. Lung Tuberculosis Control with DOTS Strategy. Higeia J Public Heal Res Dev. 2018;2(2):331-41.

10. The Union. A Dangerous Combination - Cigarettes and COVID-19: A Call for Action for Governments.
Int Union Against Tuberc Lung Dis (The UNION). 2020;1-5.

11. Wulandari RD, Laksono AD, Sandra C. Individual Characteristics and Media Exposure as Predictors of Smoking Behavior among Married Men in Indonesia. J Crit Rev. 2020;7(19):9756-63.

12. Khan AH, Sulaiman SASH, Azmi M, Khan KU, Long Chiau Ming OM and MOU. Effect of smoking on treatment outcome among tuberculosis patients in Malaysia; a multicenter study. BMC Public Health. 2020;20:854.

13. Laksono AD, Wulandari RD, Rukmini R, Matahari R. Determinant of Smoking Behavior among Childbearing Age Women in Indonesia. Int $\mathrm{J}$ Psychosoc Rehabil. 2020;24(8):6292-303.

14. Kemenkes RI. Tuberculosis Data and Information. Kementeri Kesehat RI. 2018;1-8.

15. Laksono AD, Wulandari RD. Determinant of the Puskesmas Utilization in Madura Island. Indian J Public Heal Res Dev. 2019;10(11):576-81.

16. Laksono AD, Wulandari RD, Soedirham O. Regional Disparities of Health Center Utilization in Rural Indonesia. Malaysian J Public Heal Med. 2019;19(1).

17. Wulandari RD, Qomarrudin MB, Supriyanto $\mathrm{S}$, Laksono AD. Socioeconomic Disparities in Hospital Utilization among Elderly People in Indonesia. Indian J Public Heal Res Dev. 2019;10(11):18004.

18. Wulandari RD, Putri NK, Laksono AD. Socioeconomic Disparities in Antenatal Care Utilisation in Urban Indonesia. Int J Innov Creat Chang. 2020;14(2):498-514.

19. Laksono AD, Wulandari RD. The Barrier to Maternity Care in Rural Indonesia. J Public Heal From Theory to Pract. 2020; Online First.

20. Varela C, Young S, Mkandawire N, Groen RS, Banza L, Viste A. Transportation Barriers to Access Health Care for Surgical Conditions in Malawi: a cross sectional nationwide household survey 11 Medical and Health Sciences 1117 Public Health and Health Services. BMC Public Health. 2019;19(1):Article number 264. 